\title{
COVID-19-gerelateerd schoolverzuim op de basisschool
}

\section{Afwegingen van ouders en de rol van de jeugdgezondheidszorg}

\author{
T. N. de Wit · D. Wolff · J. van den Boogaard · S. A. Reijneveld
}

Published online: 23 februari 2021

(C) Bohn Stafleu van Loghum is een imprint van Springer Media B.V., onderdeel van Springer Nature 2021

\begin{abstract}
Samenvatting Inleiding. Na de heropening van de scholen per 11 mei 2020 bleef $3-5 \%$ van alle leerlingen thuis vanwege COVID-19. Vraagstelling van dit onderzoek was wat de afwegingen zijn van ouders om hun kind thuis te houden, en welke rol de jeugdgezondheidszorg (JGZ) hierbij speelt.

Methode: Kwalitatief onderzoek bestaande uit semigestructureerde interviews met vijf schoolmedewerkers (van drie reguliere basisscholen en twee speciaal (basis) onderwijsscholen) en ouders van vier gezinnen die hun kind(eren) thuis hebben gehouden, in Groningen. De interviews zijn thematisch geanalyseerd.

Resultaten: De gepercipieerde risico's voor de gezondheid van een van de gezinsleden was de meest voorkomende reden om een kind niet naar school te laten gaan. Andere redenen waren zorgen over de gezondheid van het kind zelf en een algemene angst voor het virus, zonder dat er gezinsleden waren die binnen de risicogroepen vielen. De JGZ is nauwelijks bij de afweging van ouders betrokken geweest.

Conclusie: Dit onderzoek naar COVID-19-gerelateerd schoolverzuim op basisscholen laat zien dat ouders angstig zijn vanwege de gezondheidsrisico's voor hun gezin, ook in een regio met een lage besmettingsgraad, zoals Groningen in de eerste COVID-19-golf. De rol die de JGZ voor scholen en ouders kan spelen was in deze fase van de epidemie onvoldoende bij hen bekend.
\end{abstract}

T. N. de Wit $(\bowtie) \cdot$ Dr. D. Wolff · Dr. J. van den Boogaard GGD Groningen, Groningen, Nederland t.n.de.wit@outlook.com

Dr. D. Wolff · Prof.dr. S. A. Reijneveld afdeling Sociale Geneeskunde, UMCG, Groningen, Nederland
Trefwoorden COVID-19 - Schoolverzuim . Jeugdgezondheidszorg · Basisschoolleerlingen

\section{Inleiding}

Per 11 mei 2020 herstartten de basisscholen hun klassikale lesprogramma, na bijna twee maanden gesloten te zijn in verband met de uitbraak van COVID19. De zorgen om COVID-19 en het thuishouden van schoolgaande kinderen speelden vanaf het begin van de epidemie bij veel ouders en zorgprofessionals. Die zorgen leidden er mede toe dat het kabinet besloot om de scholen per 16 maart 2020 te sluiten [1]. Half april bleek uit onderzoek van EenVandaag dat ouders verdeeld waren over de heropening van scholen: $50 \%$ wilde de scholen weer open, $37 \%$ wilde dat niet [2]. De Nederlandse Vereniging voor Kindergeneeskunde bracht op 1 mei een standpunt uit waarin zij stelt dat vrijwel alle kinderen veilig en zonder extra voorzorgsmaatregelen naar school kunnen gaan [3].

De zorgen van ouders vertaalden zich in hun gedrag. Uit een peiling van de Algemene Vereniging Schoolleiders (AVS) onder schooldirecteuren in het basis- en speciaal onderwijs bleek dat $3-5 \%$ van alle leerlingen in de eerste week na de heropening van de scholen uit vrees voor COVID-19 thuisbleef [4]. Uit een latere peiling van de AVS op 11 juni 2020 bleek dat nog 2,6\% van de leerlingen om de volgende redenen afwezig was: verkoudheidsverschijnselen (33\%), zorgen bij ouders (19\%), gezinsleden behorend tot een risicogroep (17\%), besmetting binnen het gezin $(6 \%)$, of andere, niet-COVID-19-gerelateerde redenen voor verzuim [5]. We beschikken echter niet over kwalitatieve gegevens over de onderliggende beweegredenen en opinies van ouders om kinderen niet naar school te laten gaan op het moment dat scholen na de lockdown weer openden. Ook is niet bekend wat 
de rol van de jeugdgezondheidszorg (JGZ) is rond de zorg en schoolgang van deze kinderen.

De vraagstelling van dit onderzoek was: welke factoren spelen een rol bij de afweging van ouders en school om een kind om een COVID-19-gerelateerde reden niet naar school te laten gaan? Welke rol heeft de JGZ hierbij?

\section{Methode}

Dit onderzoek is een kwalitatief onderzoek op basis van semigestructureerde interviews, afgenomen tussen 5 juni 2020 en 30 juni 2020.

\section{Onderzoekspopulatie}

We benaderden vijf basisscholen in de stad Groningen met verschillende leerlingenpopulaties: drie reguliere basisscholen in verschillende wijken van de stad, een school voor speciaal basisonderwijs en een school voor speciaal onderwijs, cluster 4 . Per school werd een medewerker geïnterviewd die contact onderhield met gezinnen waarin COVID-19-gerelateerd schoolverzuim voorkwam. Deze schoolmedewerkers vroegen ouders van verzuimende leerlingen deel te nemen aan ons onderzoek. We excludeerden ouders van kinderen die thuisbleven vanwege acute klachten die kunnen passen bij COVID-19, zoals verkoudheid, hoesten en/of koorts.

\section{Dataverzameling}

We verzamelden de gegevens via semigestructureerde interviews, met een topiclist voor schoolmedewerkers en voor ouders, ontwikkeld op basis van uitvoerig overleg tussen de onderzoekers. Om een indruk te krijgen van de omvang van het COVID-19-gerelateerde ziekteverzuim vroegen we de schoolmedewerkers naar het aantal afwezige leerlingen. Andere topics waren: de redenen van het COVID-19-gerelateerde schoolverzuim, de rol van de school en die van de JGZ hierbij. De door school genoemde ver- zuimredenen konden later worden onderverdeeld in 1) zorgen om de gezondheid van het gezinslid, 2) zorgen om de gezondheid van het kind zelf, 3) angst voor COVID-19, 4) overig. In de interviews met de ouders waren de topics: de redenen van het verzuim, de informatie die de basis vormde voor hun keuze, het verloop van het thuisonderwijs en de rol van de JGZ bij het verzuim. De uitgebreide topiclist is op te vragen bij de eerste auteur. Er werd doorgevraagd tot er geen nieuwe inzichten meer waren. De interviews vonden vanwege de coronamaatregelen plaats via videobellen en werden, na verkregen toestemming hiervoor van de deelnemers, opgenomen met een spraakrecorder. De interviews zijn afgenomen door de eerste auteur. Ze duurden 20 tot 40 minuten.

\section{Data-analyse en rapportage}

De opgenomen interviews zijn volledig uitgetypt. Drie onderzoekers hebben onafhankelijk van elkaar een conceptversie van de thema-indeling gemaakt op basis van de topiclist en de onderwerpen die tijdens de interviews aan bod kwamen. Vervolgens zijn de transcripten van twee interviews door twee onderzoekers gethematiseerd en gecodeerd. Hierover werd overeenstemming bereikt, zodat de definitieve thema's en subthema's konden worden vastgesteld. De overige interviews werden vervolgens door de eerste auteur gecodeerd, en door haar thematisch geanalyseerd op basis van frequent terugkerende thema's.

\section{Ethische aspecten}

Dit onderzoek is voorgelegd aan de Medisch Ethische Commissie van het Universitair Medisch Centrum Groningen en beoordeeld als niet WMO-plichtig. Van alle participanten werd schriftelijk informed consent verkregen.

Tabel 1 Achtergrondkenmerken van de geïnterviewde ouders (O) en scholen (S)

\begin{tabular}{|c|c|c|}
\hline Geïnterviewde & Gezin/school & Reden van schoolverzuim \\
\hline 01: moeder, 40 jaar & $\begin{array}{l}\text { Vader } 45 \text { jaar, kind } 8 \text { jaar en kind } 6 \text { jaar op school } 4 \text { (S4) } \\
\text { Beide ouders werkzaam, hoger opgeleid }\end{array}$ & $\begin{array}{l}\text { Jongste kind onlangs op IC opgenomen van- } \\
\text { wege luchtwegproblemen }\end{array}$ \\
\hline 02: moeder, 38 jaar & $\begin{array}{l}\text { Vader } 38 \text { jaar, kind } 13 \text { jaar op middelbare school, kind } 10 \text { jaar op S4 } \\
\text { Beide ouders niet werkzaam, hoger opgeleid }\end{array}$ & $\begin{array}{l}\text { Vader zeldzame ziekte van hart en longen, } \\
\text { beide kinderen astmatisch }\end{array}$ \\
\hline 03: moeder, vader & $\begin{array}{l}\text { Kind } 8 \text { jaar op S5, kind } 2 \text { jaar en pasgeborene half mei } \\
\text { Beide ouders werkzaam, moeder parttime, vader fulltime, hoger opgeleid }\end{array}$ & $\begin{array}{l}\text { Verwachte bevalling moeder rond heropening } \\
\text { scholen }\end{array}$ \\
\hline $\begin{array}{l}\text { 04: moeder } 46 \text { jaar, } \\
\text { vader } 46 \text { jaar }\end{array}$ & $\begin{array}{l}\text { Kind } 10 \text { jaar en kind } 8 \text { jaar op S5 } \\
\text { Beide ouders parttime werkzaam, hoger opgeleid }\end{array}$ & Hartproblematiek bij jongste kind \\
\hline S1: brugfunctionaris & \multicolumn{2}{|l|}{ Reguliere basisschool, leerlingenpopulatie met relatief veel achterstandsleerlingen } \\
\hline $\begin{array}{l}\text { S2: schoolmaatschappe- } \\
\text { lijk werker }\end{array}$ & \multicolumn{2}{|c|}{ Speciaal onderwijsschool, gericht op kinderen met psychiatrische problematiek en gedragsproblemen (cluster 4-onderwijs) } \\
\hline S3: directeur & \multicolumn{2}{|l|}{ Basisschool voor speciaal onderwijs } \\
\hline S4: intern begeleider & \multicolumn{2}{|l|}{ Reguliere basisschool, leerlingenpopulatie met veel hoogopgeleide ouders } \\
\hline S5: intern begeleider & \multicolumn{2}{|l|}{ Reguliere basisschool, leerlingenpopulatie met veel hoogopgeleide ouders } \\
\hline
\end{tabular}




\section{Resultaten}

\section{Onderzoekspopulatie}

Van alle vijf benaderde basisscholen werd een medewerker geïnterviewd. Ouders van vijf gezinnen, met kinderen op twee van de deelnemende basisscholen, wilden meewerken. Daarvan werd van vier gezinnen een ouder geïnterviewd, het vijfde gezin werd niet bereikt. Ouders van drie andere benaderde gezinnen wilden niet meewerken, omdat zij geen zin in of tijd hadden voor een interview (twee ouders) of geen meerwaarde zagen in het onderzoek (één ouder). De achtergrondkenmerken van de geïnterviewde ouders en schoolmedewerkers staan in tab. 1 .

\section{Overwegingen rond COVID-19-gerelateerd schoolverzuim}

Uit de interviews met schoolmedewerkers en ouders kwamen overwegend dezelfde thema's naar voren (tab. 2). De belangrijkste thema's zullen hieronder worden besproken. Het aantal kinderen dat per school verzuimde en de voor dit verzuim genoemde redenen staan in tab. 3.

\section{Thema 1 - gezinsfactoren}

Een gepercipieerd risico voor de gezondheid van een van de gezinsleden was de meest voorkomende reden om een kind niet naar school te laten gaan. Alle schoolmedewerkers en alle ouders noemden redenen

Tabel 2 Overzicht van thema's en subthema's per categorie

Thema's en subthema's
Overwegingen ouders rond COVID-19-gerelateerd schoolverzuim
Gezinsfactoren
- Verantwoordelijkheid/zorgen over gezondheid van gezinsleden
- Zorgen over gezondheid van het schoolgaande kind
- Eerdere ervaringen met ernstige ziekte
Kennis en overtuigingen over COVID-19
- Geloof dat COVID-19 ernstige ziekte teweeg kan brengen
- Kennis over en geloof in besmettingsgraad en kans op overdracht
- Geloof dat COVID-19 op school overgedragen kan worden
- Geloof over bestaande risicogroepen COVID-19
- Kennis over (on)mogelijkheden van het zorgsysteem
Netwerkfactoren
- Zorgprofessionals betrokken
- School betrokken
Onderwijsfactoren
- Mogelijkheid om thuisonderwijs te krijgen
- Door school genomen voorzorgsmaatregelen
Sociale factoren
Ervaring met COVID-19 in omgeving
Rol van de jeugdgezondheidszorg
Betrokkenheid van de JGZ bij het gezin
Kennis en overtuigingen over JGZ

die binnen dit thema vielen, zoals een zieke vader of hoogzwangere moeder. Soms waren er meer gezinsleden in één gezin kwetsbaar, zoals blijkt uit het volgende citaat:

O2: 'De enige reden eigenlijk is geweest de gezondheid van mijn man, hun vader. Die heeft een ernstige zeldzame ziekte... Dus je bent wel wat angstig, niet zozeer voor jezelf, alhoewel ik ook in de risicogroep val, maar meer ten opzichte van mijn man.'

Schoolmedewerkers noemden ook verschillende gezondheidsproblemen die een schoolgaand kind zelf had als reden om een kind thuis te houden, zoals diabetes mellitus, nefrotisch syndroom, astma of andere longproblematiek en hartproblematiek. Ook in de interviews met ouders kwamen de zorgen om de gezondheid van een van de kinderen naar voren:

\section{O4: 'Ze gingen allebei niet naar school, maar het} was eigenlijk om de jongste. Maar daarom hebben we de oudste ook niet naar school gelaten. De jongste is in 2018 geopereerd aan zijn hart, dus heeft toen wel op de IC gelegen, heeft een openhartoperatie gehad ... Dat hij eigenlijk nog een keer op de IC terecht zou kunnen komen. Dat was wel onze angst.'

\section{Thema 2 - kennis en overtuigingen over COVID-19}

$\mathrm{Na}$ gezinsfactoren werden kennis en overtuigingen over COVID-19 het meest genoemd als reden om kinderen thuis te houden. De angst van ouders dat COVID-19 een ernstige ziekte teweeg kan brengen leek per school sterk te wisselen, zoals blijkt uit de volgende citaten:

S1: 'En ongeveer tien gezinnen die thuisbleven wegens angst, omdat ze het gewoon eng vonden, die hadden geen medische reden om thuis te blijven.'

S5: 'Er waren heel veel zorgen bij ouders. Maar uiteindelijk viel het heel erg mee met de kinderen die er niet waren ...'

Bij de geïnterviewde ouders kwam algemene angst voor COVID-19 alleen als secundaire factor naar voren in samenhang met gezinsfactoren, niet als centrale reden om het kind thuis te houden. In veel gevallen wilden ouders afwachten of er besmettingen op school zouden plaatsvinden, voordat ze hun kind naar school lieten gaan. Schoolmedewerkers gaven aan dat bijna alle kinderen ten tijde van het interview weer op school waren. De mate waarin de regionale en landelijke besmettingsgraad werd meegewogen in de beslissing rond het schoolverzuim, verschilde per ouder.

O4: 'Ja, ook omdat er geen bewijs was dat het slechter ging of dat er meer corona kwam. Dus die informatie wel. En ja, eigenlijk "wanneer is 
Tabel 3 Aantal afwezige leerlingen per school naar de voor het verzuim genoemde reden ${ }^{\mathrm{a}}$

\begin{tabular}{|c|c|c|c|c|c|}
\hline & $\begin{array}{l}\text { Zorgen over gezondheid gezinsleden } \\
n(\%)\end{array}$ & $\begin{array}{l}\text { Zorgen over gezondheid schoolgaand kind } \\
n(\%)\end{array}$ & $\begin{array}{l}\text { Angst }^{b} \text { voor COVID-19 } \\
n(\%)\end{array}$ & $\begin{array}{l}\text { Overige redenen } \\
n(\%)\end{array}$ & $\begin{array}{l}\text { Totaal } \\
n(\%)\end{array}$ \\
\hline S1 & $3(19 \%)$ & $3(19 \%)$ & $10(62 \%)$ & - & $16(100 \%)$ \\
\hline S2 & $5(56 \%)$ & $3(33 \%)$ & $1(11 \%)$ & - & $9(100 \%)$ \\
\hline S3 & $8(53 \%)$ & $2(13 \%)$ & $3(20 \%)$ & $2(13 \%)$ & $15(100 \%)$ \\
\hline S4 & $2(40 \%)$ & $1(20 \%)$ & $2(40 \%)$ & - & $5(100 \%)$ \\
\hline S5 & $5(50 \%)$ & $2(20 \%)$ & $3(30 \%)$ & - & $10(100 \%)$ \\
\hline Totaal & $23(42 \%)$ & $11(20 \%)$ & $19(34 \%)$ & $2(4 \%)$ & $55(100 \%)$ \\
\hline
\end{tabular}

het einde?" was het bij ons. Je kan ze het hele jaar wel thuishouden, maar je moet toch een keer dat doen.'

O2: 'Wij wachten gewoon even af hoe de besmettingsgraad zich ontwikkelt nu alles weer versoepeld wordt en alles weer gewoon verder losgaat. En na de vakantie, afhankelijk van hoe de besmetting zich op dat moment hier in het Noorden voordoet, beslissen en dan gaan we een keuze maken van hoe en wat.'

\section{Thema 3 - netwerkfactoren}

Ouders overlegden over schoolhervatting met de huisarts of medisch specialist bij wie de ouder of het kind onder behandeling was en hechtten waarde aan de gegeven adviezen. Dit kon betekenen dat ze hun kind op advies van een arts thuishielden, maar ook dat ze het kind na overleg met een arts toch naar school lieten gaan.

O4: 'Wij hebben gebeld met de huisarts. Die kon ons niet een advies geven of een zwart-witadvies geven. Het is niet handig om naar school te gaan of ja, doe maar. Maar hij heeft eigenlijk onofficieel gezegd: "Als het mijn zoon was, liet ik hem nog even thuis."'

Het initiatief om voor advies contact met de behandelend arts op te nemen kwam meestal van de ouders zelf. In twee gevallen hebben scholen ouders aangeraden contact te zoeken.

\section{De rol van de JGZ bij COVID-19-gerelateerd schoolverzuim}

Geen van de geïnterviewde ouders had contact met de JGZ over het COVID-19-gerelateerde schoolverzuim van hun kinderen. Meestal was er rechtstreeks contact over het schoolverzuim tussen ouders en school. Twee van de vijf geïnterviewde schoolmedewerkers hadden overleg met de JGZ over enkele individuele casussen. Schoolmedewerkers gaven aan nu geen grote rol voor de JGZ te zien, alleen bij een uitbraak op school of als spil tussen zorg en onderwijs bij echt medische problemen.
Schoolmedewerkers gingen er vanuit dat ouders zelf om contact met de JGZ zouden vragen als ze daar behoefte aan hebben. In de interviews met ouders bleek echter dat drie van de vier gezinnen geen idee hadden wat de JGZ voor ze zou kunnen betekenen wat betreft COVID-19-gerelateerd schoolverzuim. Na enige toelichting over de rol van de JGZ gaven alle ouders aan op dit moment geen behoefte te hebben aan betrokkenheid van de JGZ voor hun eigen gezin, maar het niet erg te hebben gevonden als dit was aangeboden. Voor andere gezinnen zagen ze wel een rol, maar dat betrof soms een rol die niet bij de JGZ paste, zoals ondersteuning bij het thuisonderwijs.

O1: 'Ik denk meer voor mensen die echt in de problemen raken, die het gewoon niet kunnen bolwerken om zelf thuisonderwijs te geven ... Maar ik denk dat [de JGZ] echt voor mensen is die uit een minder sociaal milieu komen die het misschien nog wel lastig vinden of die zelf niet genoeg onderwijs hebben genoten. Waardoor het moeilijk kan zijn hun eigen kinderen te helpen, zeker als het hogere klassen zijn, dat het lastig kan worden.'

\section{Beschouwing}

Dit eerste verkennende onderzoek naar factoren die een rol spelen bij COVID-19-gerelateerd schoolverzuim op de basisschool laat zien dat ouders zich zorgen maken over de gezondheidsrisico's voor hun gezin, ook in een regio met een lage besmettingsgraad, zoals Groningen. De JGZ speelde bijna geen rol in hun afwegingen.

Gepercipieerde risico's voor de gezondheid van een van de gezinsleden was de meest genoemde reden voor schoolverzuim. Andere redenen waren zorgen over de gezondheid van het kind zelf en een algemene angst voor het virus zonder dat er gezinsleden waren die tot een risicogroep behoorden. Dit komt overeen met de peiling van de AVS op 11 juni 2020 [5]. Het Rijksinstituut voor Volksgezondheid en Milieu (RIVM) heeft duidelijk gedefinieerd welke personen tot de risicogroepen behoren en stelt dat kinderen met onderliggende medische problematiek geen groter risico lijken te lopen op een ernstig beloop van COVID-19 dan gezonde kinderen [6, 7]. De percentages kinderen 
die thuisbleven en de daarvoor bij scholen opgegeven redenen doen vermoeden dat meer mensen het idee hebben tot een risicogroep te behoren dan de richtlijn aangeeft. In lijn met het advies van het RIVM en de Nederlandse Vereniging voor Kindergeneeskunde is het dus belangrijk dat artsen schoolhervatting alleen ontraden als daar gegronde gezondheidsredenen voor zijn [3, 7].

Het Nederlands Centrum Jeugdgezondheidszorg geeft aan dat de JGZ een vitale rol heeft als medische vraagbaak en adviseur in tijden van de COVID-19epidemie [8]. De AJN Jeugdartsen Nederland heeft beslisbomen opgesteld voor het handelen bij thuisblijven van kinderen in het COVID-19-tijdperk [9]. Daarin speelt de JGZ een adviserende rol. Uit ons onderzoek blijkt echter dat de JGZ nauwelijks betrokken was bij de afweging van ouders, niet door ouders en niet door scholen. De geïnterviewde ouders geven aan geen behoefte te hebben aan betrokkenheid van de JGZ. Uit hun antwoorden blijkt echter ook dat onvoldoende bekend is welke rol de JGZ als verbinder tussen ouders, school en behandelend artsen kan spelen. Schoolmedewerkers gaven aan te verwachten dat ouders zelf contact met de JGZ opnemen als ze daar behoefte aan hebben. Zelf betrekken ze de JGZ alleen als er medische problemen zijn.

Een sterk punt van dit onderzoek is dat de interviews vlak na de heropening van de scholen op 11 mei 2020 zijn afgenomen, bij zowel schoolmedewerkers als ouders. Het geeft daarmee inzicht in de manier waarop ouders afwegingen maken in een situatie waarin nog veel onbekend is over de verspreiding van het coronavirus op scholen. Verder omvatte het onderzoek zowel schoolmedewerkers van reguliere basisscholen als medewerkers van speciaal(basis)onderwijsscholen uit verschillende wijken van de stad Groningen.

Beperkingen zijn dat het onderzoek alleen de stad Groningen betreft en dat van slechts twee basisscholen ouders meededen. Dit waren reguliere basisscholen met voornamelijk hoog opgeleide ouders. De informatie van de schoolmedewerkers is dan ook belangrijk om het beeld te completeren. Daarnaast hebben we een klein aantal interviews met ouders afgenomen. Hoewel op de meeste thema's uit de topiclist na enkele interviews geen nieuwe informatie meer naar voren leek te komen, was het aantal afgenomen interviews te klein om zeker te kunnen zijn van datasaturatie. Aanvullend onderzoek is nodig om te bepalen of de overwegingen van ouders onveranderd zijn nu COVID-19 blijft circuleren en de kennis erover toeneemt, en of de huidige bevindingen representatief zijn voor de rest van Nederland en voor andere groepen, zoals ouders met een migratieachtergrond of een praktijk-/beroepsopleiding.

Concluderend laat dit onderzoek zien dat angst een belangrijke factor was voor ouders om hun kind na de heropening van de scholen op 11 mei 2020 thuis te houden, bij gezinnen met en bij gezinnen zonder gezinsleden in een risicogroep. De JGZ kan een adviserende rol spelen om deze angst weg te nemen, maar werd in deze fase van de epidemie door scholen en ouders nauwelijks betrokken in de afweging om kinderen naar school te laten gaan. De JGZ kan hier veel winst boeken en wij bevelen aan om deze kans met de aanhoudende COVID-19-epidemie aan te grijpen.

\section{Literatuur}

1. Rijksoverheid. Aanpak coronavirus vraagt om tijdelijke sluiting scholen en kinderdagverblijven. Den Haag: Rijksoverheid. 2020. www.rijksoverheid.nl/ actueel/nieuws/2020/03/15/corona-aanpak-vraagt-omtijdelijke-sluiting-scholen-en-kinderdagverblijven. Geraadpleegd op: 15 mei 2020.

2. EenVandaag. Ouders diep verdeeld over heropenen basisscholen: 'Thuisonderwijs is te belastend. https:// eenvandaag.avrotros.nl/panels/opiniepanel/alle-uitsla gen/item/ouders-diep-verdeeld-over-heropenen-basis scholen-thuisonderwijs-is-te-belastend/ (Gecreëerd: 15 apr 2020). Geraadpleegd op: 18 mei 2020.

3. Nederlandse Vereniging voor Kindergeneeskunde. Standpunt Het coronavirus (COVID-19) en kinderen. Utrecht: Nederlandse Vereniging voor Kindergeneeskunde. 2020. https://www.nvk.nl/over-nvk/vereniging/dossiers-en-st andpunten/covid-19/document-covid-19?dossierid=2654 2080. Geraadpleegd op: 15 mei 2020.

4. ANP. Ruim 50.000 kinderen en twee procent van de leraren na heropening niet naar school. https://nos.nl/artikel/ 2333813-ruim-50-000-kinderen-en-twee-procent-vande-leraren-na-heropening-niet-naar-school.html (Gecreëerd: 14 mei 2020). Geraadpleegd op: 15 mei 2020.

5. Algemene Vereniging Schoolleiders. Heropening scholen verloopt goed, wel uitdagingen rond personeelstekort. Utrecht: Algemene Vereniging Schoolleiders. 2020. https:/ / avs.nl/actueel/nieuws/heropening-scholen-verlooptgoed-wel-uitdagingen-rond-personeelstekort/. Geraadpleegd op: 14 sep 2020 .

6. RIVM. Watzijnderisicogroepen bijhetnieuwe coronavirus? Bilthoven: RIVM. 2020. https://www.rivm.nl/coronaviruscovid-19/risicogroepen. Geraadpleegd op: 18 sep 2020.

7. RIVM. Kinderen en school en COVID-19. Bilthoven: RIVM. 2020. https://www.rivm.nl/coronavirus-covid-19/ kinderen. Geraadpleegd op: $18 \operatorname{sep} 2020$.

8. Nederlands Centrum Jeugdgezondheidszorg. Coronavirus. Onderwerpen A-Z. Utrecht: Nederlands Centrum Jeugdgezondheidszorg. 2020. https://www.ncj.nl/themadossiers/ coronavirus/onderwerpen-a-z/. Geraadpleegd op: 9 nov 2020.

9. AJN Jeugdartsen Nederland. Beslisboom neusverkouden kinderen (AJN - BOinK + RIVM). Utrecht: AJN Jeugdartsen Nederland. 2020. https://ajnjeugdartsen.nl/wpcontent/uploads/2014/04/Beslisboom-neusverkoudenkind-7-t_m-12-jaar-toelaten-op-kinderopvang_school_ AJN_BOinK_RIVM.pdf. Geraadpleegd op: 9 nov 2020.

T.N. de Wit, hoofdonderzoeker, jeugdarts in opleiding

Dr. D. Wolff, jeugdarts, onderzoeker

Dr. J. van den Boogaard, arts infectieziektebestrijding

Prof.dr. S.A. Reijneveld, hoogleraar Sociale geneeskunde 